\title{
Sprog og krop - Psykolingvistik i Danmark
}

\author{
LINE BURHOLT KRISTENSEN
}

Psyko- og neurolingvistiske undersøgelser er i opblomstring blandt danske sprogforskere. Denne artikel giver en grundlæggende indføring i hvad neurolingvistik og psykolingvistik er, og hvordan disse tilgange adskiller sig fra andre sprogvidenskabelige discipliner. Gennem eksempler fra samtidig dansk forskning argumenteres der for neuro- og psykolingvistikkens potentiale i en dansk sammenhæng: De kan bidrage til udforskningen af det danske sprog, ligesom forskning i dansk sprog kan bidrage til besvarelsen af neuro- og psykolingvistiske kernespørgsmål. Psykolingvistikkens metoder er ikke oprindeligt udviklet med sprogvidenskabelige spørgsmål for øje, men giver nye muligheder for indsigt $\mathrm{i}$ hjernens arbejde med sprog og i sammenhænge mellem sprog og kognition. Metoderne er dog også underlagt en række praktiske begrænsninger der gør det svært at undersøge sprog og kognition som situationelt og interaktionelt forankret.

EMNEORD: kognition, neurolingvistik, psykolingvistik, forskningstraditioner, validitet

\section{INDLEDNING}

Det er ikke nyt at sprogforskere interesserer sig for sammenhænge mellem sprog og mentale processer som $\mathrm{fx}$ at huske og planlægge. Men det er relativt nyt at de har fået adgang til naturvidenskabelige værktøjer der kan måle hvad der sker i os når vi taler, lytter og læser. Siden 1990'erne har danske sprogforskere kunnet tilgå avanceret udstyr som reaktionstidsmålere, eye-trackere og hjerneskanningsudstyr og undersøge forskningsspørgsmål om sammenhængen mellem sprog og mentale processer. Hvordan påvirker hjernens arbejde vores sprogbrug? Og omvendt, hvordan påvirker sprogbrugen den måde hjernen 
arbejder på? Hvilke sammenhænge er der mellem hjernens struktur og sprogstrukturer?

Der er håb om at indsigter fra psykologi og neurobiologi kan gøre os klogere på teoretiske spørgsmål om sprog, herunder om dansk. Her kan psykolingvistikken ses som en del af en bredere humanvidenskabelig strømning der debatterer "[...] hvorvidt der er aspekter af menneskets adfærd, som ikke kun lader sig beskrive gennem introspektive, sociologiske eller kulturanalytiske metoder, men også kræver bidrag fra naturvidenskaben " (Wiben Jensen \& Skov 2007:7).

Formålet med denne artikel er at give en introduktion til psykolingvistikken (herunder neurolingvistikken) som et forskningsfelt i Danmark. Harder (2006) omtaler kort "den integration der er i gang, mellem den strukturelt lingvistiske, den kognitivt-lingvistiske og den empirisk psykolingvistiske tilgang til sproglige fænomener" (Harder 2006:125), og Tylén og Wallentin (2015) giver eksempler fra psykolingvistikken i en introduktion til brugen af eksperimentelle metoder i humaniora. Denne artikel giver en samlet introduktion til de psykolingvistiske tendenser i dansk sprogforskning.

Efter en generel introduktion til psykolingvistik gives eksempler på hvordan den psykolingvistiske forskning kan indgå i udforskning af dansk sprog - og omvendt. Der fokuseres på studier af raske talere af dansk og i mindre grad på klinisk forskning med særlige populationer, fx personer med ordblindhed, afasi eller skizofreni. I relation til temanummeret diskuteres til slut psykolingvistikkens muligheder og begrænsninger i forhold til udforskning af sprog som handling.

\section{HVAD ER PSYKOLINGVISTIK?}

Psykolingvistik er studiet af menneskers handlinger og mentale processer når de bruger sprog (Clark 1999:688). Det kan være undersøgelser af noget så forskelligt som læsning, sprogtilegnelse og hverdagssamtaler. Nogle psykolingvistiske undersøgelser har et rent teoretisk sigte ( $\mathrm{fx}$ at afdække og modellere hvordan man læser), mens andre former for psykolingvistisk forskning har et klinisk sigte. De kan undersøge behandling af ordblindhed, stammen, sprogindlæring, afasi og andre sproglige vanskeligheder. 
Det gælder overordnet for psykolingvister at de undersøger "mechanisms and operations involved in producing and understanding language" (Libben 1997: 438), men derudover undersøger de alle niveauer af sprog fra fonetik til diskursteori. De samles om interessen for sprog og kognitive processer, men kan ikke nødvendigvis enes om den teoretiske ramme der spænder fra generativ grammatik til funktionel lingvistik og til teorier med oprindelse uden for sprogvidenskaben, $\mathrm{fx}$ evolutionære teorier.

Betegnelsen psykolingvistik kan (ifølge Levelt 2012) spores til året 1951, hvor Cornell University afholdt et tværdisciplinært sommerseminar om sprog og psykologi. Gennem 1950'erne fik psykolingvistikken for alvor opmærksomhed i USA gennem Noam Chomsky og George Miller. Efter en periode hvor behaviorismen og strukturalismen havde domineret, blev det med Chomsky igen populært at forske i hvad der sker $i$ sprogbrugeren.

Selv om den moderne psykolingvistik først blev etableret som disciplin i 1950'erne, er interessen for sprogets psykologi af ældre dato. 1800-tallet bød på store hjernevidenskabelige gennembrud, deriblandt den franske kirurg Paul Brocas undersøgelser af taletab i forbindelse med hjerneskade. I 1861 rapporterede Broca fundet af en patient, Hr. Leborgne, der efter en hjerneskade i pandelappen havde mistet talen. Han sagde ikke andet end "tan" og "tantan". Broca så en sammenhæng mellem Leborgnes hjerneskade og hans sprogproblem. I årene der fulgte, obducerede Broca en række patienter med lignende taletab. Der viste sig et mønster: 8 patienter havde alle både taletab (afasi) og en læsion i den venstre pandelaps tredje foldning. Senere i 1800-tallet opdagede den tyske læge Karl Wernicke at afasi også kunne opstå ved hjerneskader i den øvre del af hjernens venstre tindingelap. Brocas område og Wernickes områder anses fortsat for vigtige sprogområder - senere studier har vist at de sammen med andre områder af hjernen indgår i komplekse netværk for sprogprocessering. 


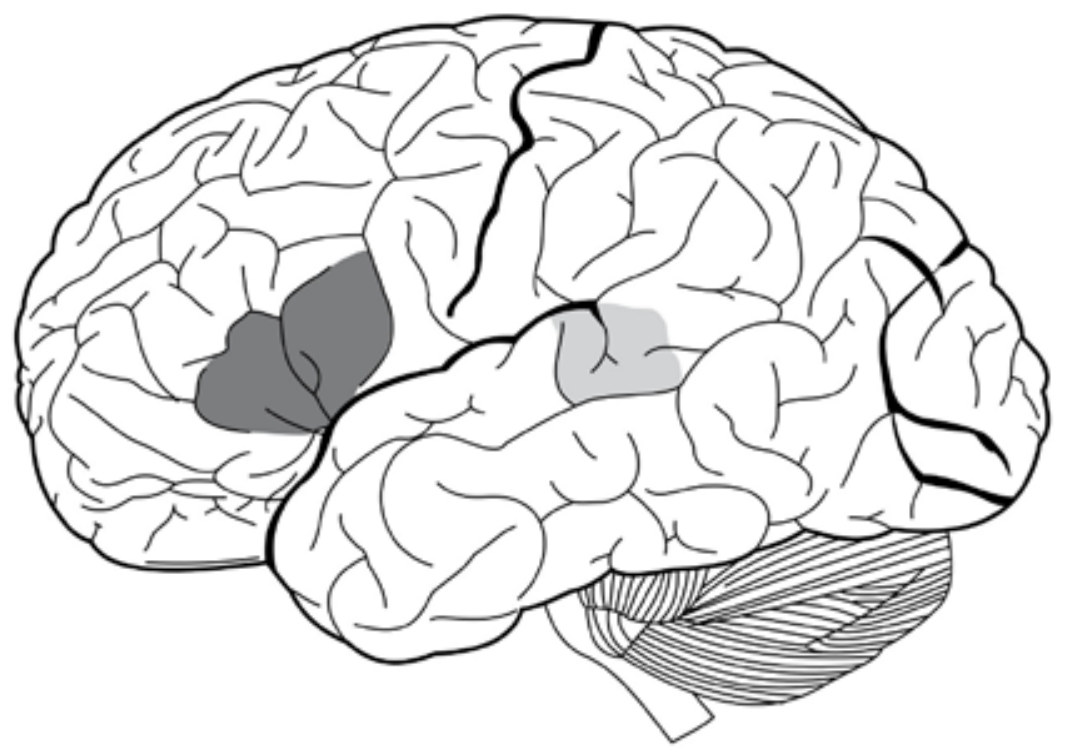

1800-tallet var også en periode hvor tyske og franske forskere førte journaler over børns sprogtilegnelse og tegnede diagrammer over hjernens funktionelle arkitektur. Nogle tanker og modeller er i modificeret form fortsat indflydelsesrige. Andre er for længst forkastede, bl.a. Galls frenologi som antog at menneskets kranie tog form efter sindet (Levelt 2012). Hvor datidens forskere var afhængige af metoder som journalisering og obduktion, er der i dag mange nye værktøjer til at måle hvad der sker i sprogbrugeren - især hvor og hvornår.

\subsection{Neurolingvistik versus psykolingvistik}

Disciplinerne neurolingvistik og psykolingvistik er tæt forbundne: Neurolingvistik er en slags psykolingvistik (Ahlsen 2006). Hvor psykolingvistikken ser bredt på sprog og psykologiske mekanismer, har underdisciplinen neurolingvistik et mere snævert fokus på studier af sprog $i$ bjernen og måler eller modellerer noget der relaterer sig til hjernens hjerneceller (neuronerne): 
Neurolinguistics studies the relation of language and communication to different aspects of brain function, in other words it tries to explore how the brain understands and produces language and communication. This involves attempting to combine neurological/neurophysiological theory (how the brain is structured and how it functions) with linguistic theory (how language is structured and how it functions). (Ahlsen 2006:3)

Neurolingvister kan (som Broca og Wernicke) studere patienters sprog og kommunikation efter en hjerneskade. Men mange af nutidens neurolingvister studerer i stedet raske menneskers sprog og kommunikation via hjerneskanninger, it-simulationer og eksperimenter. Herigennem kan de udforske hvordan sprog processeres over tid og hvilke hjerneområder og netværk der er involveret.

\subsection{Relationen til andre forskningsfelter}

Psykolingvistik (med neurolingvistikken som underdisciplin) kan ses som en slags kognitionsvidenskab:

Kognitionsvidenskab > Psykolingvistisk $>$ Neurolingvistik

Kognitionsvidenskaben beskæftiger sig som udgangspunkt med hvordan tanker, hukommelse og erkendelse er organiseret og implementeret $i$ hjernen. Kognitionsforskere er interesseret $i$ en lang række kognitive fænomener - deriblandt sprog. Men psykolingvistik kan også ses som en type psykologi eller en type sprogvidenskab (deraf navnet).

Psykologi $>$ Psykolingvistik

Lingvistik > Psykolingvistik

Psykologiens erkendelsesinteresse fokuserer på mentale og sociale funktioner - deriblandt sproglige processer. Lingvisters erkendelsesinteresse er som udgangspunkt hvad sprog er, og hvordan det bruges, og de kan derfor også interessere sig for hvad der sker i sprogbrugerne.

Endelig kan neurolingvistikken ses som en type neurovidenskab, der igen er en type biologi, idet neurolingvistikken bidrager med viden om 
menneskekroppens indretning og funktioner, og om hvordan den adskiller sig fra andre dyrs.

\section{Biologi $>$ Neurovidenskab $>$ Neurolingvistik}

Nogle psykolingvister (heriblandt undertegnede) tager primært udgangspunkt $i$ lingvistikkens temaer og erkendelsesinteresser. Men psykolingvister kan også have en faglig baggrund som eksempelvis psykolog, audiologopæd, filosof, kognitionsforsker, neurolog, biolog eller kemiker.

\subsection{De centrale sporgsmål}

Psykolingvister kan undersøge om et sprogs struktur eller en bestemt sprogbrug påvirker menneskers kognition, fx hvordan de kategoriserer objekter (Bowerman \& Choi 2001). Eller de kan omvendt undersøge om strukturer i de mentale processer påvirker sprogets mulige strukturer eller måden sproget bruges på, fx om belastninger på arbejdshukommelsen begrænser hvor indviklede forståelige sætningsstrukturer kan være (MacDonald m.fl. 1992). På samme måde kan neurolingvisters interesse for forholdet mellem sprog og hjerne gå begge veje. De kan undersøge om hjernens struktur påvirkes af at lære et nyt sprog (Mechelli m.fl. 2004), eller de kan undersøge hvordan hjernens indretning og mekanismer kan forklare sprogstrukturer og sprogbrug.

Psykolingvistikkens tværdisciplinære baggrund er på en gang en velsignelse og en sten i skoen. Det er en fordel, fordi psykolingvister kan trække på teoretiske indsigter og metodiske værktøjer fra et hav af discipliner og kan knytte disciplinerne tættere til hinanden og sikre en gensidig berigelse. Men det er også en ulempe fordi psykolingvister, trods fælles overordnede spørgsmål, trækker forskningen i mange forskellige retninger og ofte har svært ved at forstå hinandens teorier, metoder og hensigter. Man kan eksempelvis ikke forvente at psykologer og neurologer kender forskel på bøjning og afledning og kan se det relevante $\mathrm{i}$ at undersøge de kognitive processer bag. Eller at sprogforskere kender til neuroanatomi og forstår hvorfor det skulle være teoretisk relevant at substantiver og verber aktiverer forskellige områder af hjernen. 
Neurolingvistikken er ifølge Poeppel og Embick (2005) fanget i krydsfeltet mellem sprogvidenskaben på den ene side og neurologien på den anden. Dels er de to discipliner ontologisk forskellige (ontological incommensurability problem), dels har deres forskningsspørgsmål forskellige detaljeringsgrader (granularity mismatch problem): Neurologien er på nuværende tidspunkt i stand til at besvare overordnede spørgsmål om sprog, fx om der er forskel på hjernens arbejde med grammatik vs. fonologi (Sahin m.fl. 2009). Men disse overordnede spørgsmål er sjældent interessante for sprogforskere. Sprogforskere er på forhånd enige om at der er forskel på fonologi og syntaks - det tilsiger al sproglig analyse. De sprogvidenskabelige problemstillinger handler om mere spidsfindige detaljer, $\mathrm{fx}$ den mentale repræsentation af kasusforskellen mellem han og ham. Men hjerneskanninger og lignende neurovidenskabelige metoder er på nuværende tidspunkt formentlig ikke fintfølende nok til at registrere om der overhovedet er en sådan forskel på han og ham (selvom der nødvendigvis må være det - hvordan skulle vi ellers kunne bruge den i sproget?). Problemet er altså at neurolingvistikken, selvom den kan besvare mange spørgsmål om sprog i hjernen, ikke kan besvare mange af de detaljerede spørgsmål der kan informere sprogvidenskabelige teorier. Nogle overordnede problemstillinger er dog også interessante for almene sprogforskere, såsom om sprog er medfødt eller ej.

\subsection{Metoder}

Psykologien, neurologien, lingvistikken og andre nabodiscipliner har hver især udviklet metoder som psykolingvister kan benytte sig af og kombinere. Psykolingvister bruger fortrinsvis kvantitative metoder der måler kropslig adfærd, sproglig adfærd eller mental aktivitet. Men de kan også arbejde med kvalitative data. Eller lave modeller på baggrund af andre forskeres data uden selv at udføre eksperimenter. Herunder følger nogle eksempler på hvordan psykolingvistiske undersøgelser kan tilrettelægges, fra klassiske adfærdseksperimenter, til korpusundersøgelser og endelig eksempler på neurolingvistiske undersøgelser.

2.4.1 Adfardseksperimenter måler forsøgsdeltageres adfærd. Det kan være den måde deltageren taler på, hvor deltageren kigger hen, eller hvor 
hurtig deltageren er til at trykke på en knap. Et adfærdseksperiment kan være et læseeksperiment hvor forsøgsdeltagerne læser to typer af sætninger på en skærm og hvor deltagernes læsetider for de to sætningstyper sammenlignes. I Kristensen m.fl. (2014) læste deltagerne transitive sætninger med to typer ordstilling fx Kasper ville dog invitere Else til fodselsdagen (med subjektet i forfeltet) vs. Else ville Kasper dog invitere til fodselsdagen (med objektet først). Sætningerne blev vist et ord ad gangen på en computerskærm, og deltagere trykkede sig videre hver gang de var klar til at se et nyt ord. Forsøgets procedure er illustreret i Figur 2.

FIGUR 2. PROCEDURE FOR VISNING AF SKÆRMBILLEDER I KRISTENSEN ET AL. (2014).

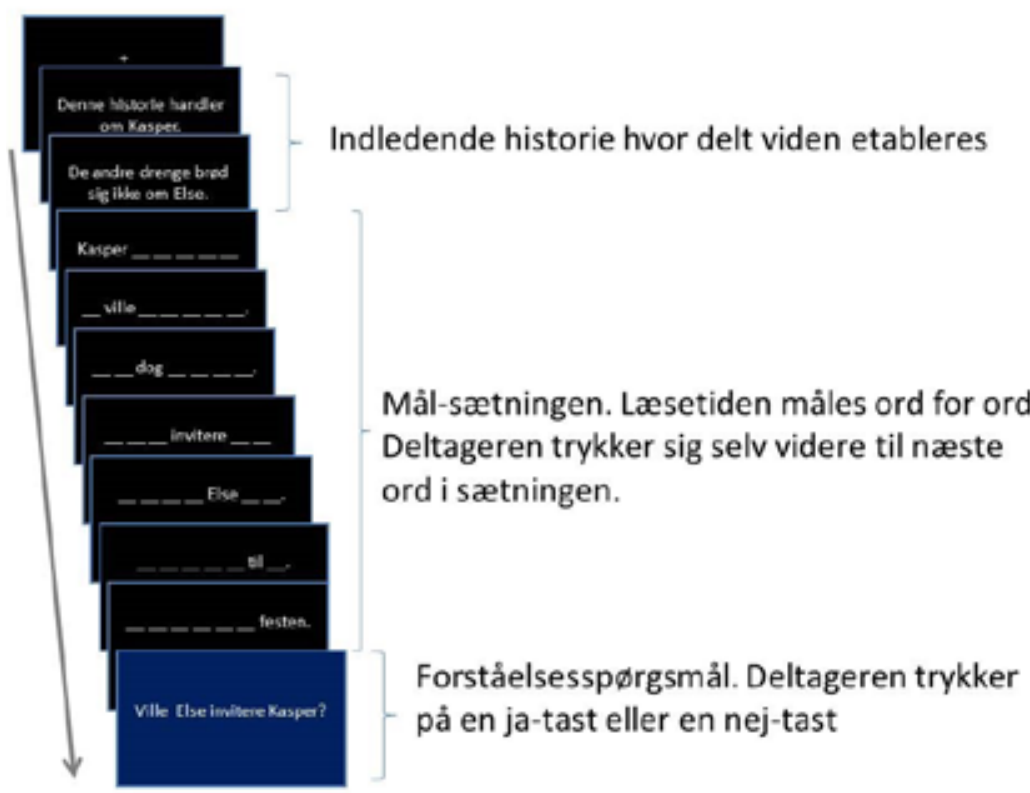

Figuren viser en af $i$ alt 96 runder $i$ forsoget. Hver runde starter med visning af et fikseringskryds. Dernast vises en indledende historie bvor delt viden etableres mellem afsenderen og forsogsdeltageren. Derpå vises mål-satningen ord for ord. Forsogsdeltageren kan selv trykke sig videre til naste ord, og lasetiden registreres af programmet. Sidst $i$ bver runde svarer deltageren på et forstålsessporgsmål. Svaret og svartiden registreres af programmet.

Forsøget viste bl.a. at deltagerne var længere tid om at læse sætninger med objektet først, og det kunne også vise hvor i sætningen læsetiden 
blev længere. Den lange læsetid kan tolkes som ekstra kognitiv belastning ved sætninger med objektet først. Deltagerne skulle efter hver sætning svare på et forståelsesspørgsmål ved at trykke på en ja-knap eller en nej-knap. En sammenligning mellem de to typer sætninger viste at deltagerne både svarede mere forkert og langsommere på de spørgsmål der efterfulgte sætninger med objektet først. Deltagerne var altså både længere tid om at læse sætninger med objektet først, og de var dårligere til at forstå dem og langsommere i deres reaktion på forståelsesspørgsmål. Fremgangsmåden med at præsentere stimuli (her sætninger på skrift), manipulere en eller flere variable (her sætningens ledstilling) og måle en anden variabel (læsetid, responstid eller svarkorrekthed) er udbredt i psykolingvistisk forsøg. Stimuli kan være skriftligt eller talt sprog, billeder, video, fysiske objekter m.m. Manipulationen kan også varieres afhængigt af undersøgelsesspørgsmålet. Man kan sammenligne rigtige ord vs. nonsensord, to relaterede ord vs. to ikke-relaterede ord, passivsætninger vs. aktivsætninger, ord med stød vs. stødløse ord osv. Den målbare variabel kan tage mange former: I stedet for at måle knaptryk, kan man måle hvad deltageren siger eller hvordan deltageren gestikulerer. Med udstyr som en eye-tracker kan man også måle øjets adfærd, fx hvordan folk læser avisartikler eller hjemmesider.

Adfærdseksperimenter er typisk meget kontrollerede. Sætningerne der sammenlignes i Kristensen m.fl. (2014), er fx meget ens hvad angår indhold, så det er entydigt at forskellen mellem de to sætninger netop skyldes ledstilling og ikke skyldes at den ene type sætninger var længere end den anden eller handlede om nogle helt andre emner. Desuden er det vigtigt at stimuli præsenteres under de samme forhold, så psykolingvistiske eksperimenter foregår ofte i et stille lokale. På den måde kan man undgå at deltageren påvirkes af udefrakommende stimuli ( $\mathrm{fx}$ støj eller andre samtaler) under læsningen. Men mere naturalistiske forsøgsformer vinder også frem (jf. 4.1).

2.4.2. Korpusstudier er en sprogvidenskabelig specialitet og kan også være psykolingvistisk anlagte. Psykolingvistiske modeller som Bock \& Levelt (1994) er baseret på korpusundersøgelser af talefejl og fortalelser. Ved at studere de mønstre der optræder i talefejl, kan man fx undersøge hvor mange sproglige enheder sprogbrugeren planlægger 
ad gangen. En forveksling af dear old queen med queer old dean kunne tyde på at taleren har planlagt ord nummer 3 allerede før første ord ytres. Men også samlinger af naturlig tale uden fortalelser kan give indsigt i mekanismer bag hjernens arbejde med at producere og bearbejde sprog, fx i hvordan sprogbrugere tilpasser sig hinanden i samtale (alignment: Fusaroli m.fl. 2012). Undersøgelser af pausers forekomster i talesprog kunne også give indsigt $\mathrm{i}$ hvilke ord der er svære at producere.

Foruden naturlig tale findes sammenligninger af personer med forskellige sprog eller fra forskellige aldersgrupper der gengiver den samme historie, fx en billedbog uden ord. Sproglige mønstre i narrativerne kan bl.a. belyse forskelle mellem aldersgrupper og sprog (Engberg-Pedersen 2000) eller mønstre i tilegnelsen af et fremmedsprog.

2.4.3 Patientstudier. En række psykolingvistiske studier fokuserer på patientgruppers sprog og på børnesprog, herunder longitudinale casestudier, der følger et barns sprogtilegnelse over tid, eller en patient gennem et optræningsforløb. Der findes også kontrastive studier som sammenligner børns sprog i forskellige aldersgrupper eller sproglig adfærd hos en patientgruppe ( $\mathrm{fx}$ personer med skizofreni) med en kontrolgruppe.

2.4.4 Neurolingvistiske undersøgelser tæller, foruden studier af særlige patientgruppers sprog, studier med metoder der påvirker eller indirekte måler eller simulerer hjernens aktivitet. Nogle teknikker er udviklet til at måle de elektriske impulser der opstår når hjernen er aktiv. Andre bruger magnetiske felter og radiobølger til at danne billeder af hjernen. Neurolingvistiske metoder relaterer sig direkte til hjernens nerveceller (neuroner) og adskiller sig dermed fra andre psykolingvistiske teknikker som læsetider og eye-tracking der ikke måler neuroners aktivitet eller struktur. De neurolingvistiske metoder har hver deres fordele og ulemper.

En effektiv måde til at registrere hjernens aktivitet er at montere elektroder direkte på hjernebarken. Denne metode kræver dog et åbent kranie (!) og udføres derfor kun i forbindelse med en operation hvor kraniet alligevel skulle åbnes (jf. Sahin m.fl. 2009). Heldigvis findes der mange metoder der ikke kræver indgreb. Elektroencefalografi (EEG) 
er et harmløst alternativ hvor forsøgsdeltageren får påmonteret en EEG-hætte med elektroder der på hovedbunden kan måle ændringer i elektriske impulser. EEG-signalet kan analyseres på mange forskellige måder - inden for psykolingvistikken er metoden ERP (event-related potentials) den hyppigst brugte. I ERP-studier måles de elektriske impulser der knytter sig til en bestemt type stimuli, fx ordet dog i en sætning som I take my coffee with cream and dog. Semantisk afvigende ord som dog giver, i sammenligning med et forventet ord som sugar, et negativt udsving i det elektriske signal cirka 400 millisekunder efter visning af ordet (kaldet N400; se Kutas \& Hillyard 1980). På den baggrund kan man belyse timingen af semantiske processer.

Da EEG/ERP fortæller hvornår noget sker, men ikke hvor, må man bruge andre metoder til at undersøge hvilke områder af hjernen der arbejder med sprog. Den mest udbredte hjerneskanningsmetode er MR (der bygger på Magnetisk Resonans), men neurolingvister anvender også andre metoder som PET (position-emissions-tomografi) og den nyere metode MEG (magnetencefalografi).

Med MR kan man foretage forskellige typer hjerneskanninger. Strukturelle skanninger kan danne billeder af hjernens struktur der bl.a. kan vise den præcise placering af en hjerneskade. Diffusionsvægtede skanninger kan bl.a. bruges til at undersøge forbindelser mellem hjerneområder. Endelig kan funktionelle skanninger give et indblik i hvilke områder af hjernen der er aktive under arbejdet med en sproglig opgave. Funktionel magnetisk resonans-billeddannelse (fMRI) måler ikke hjernens aktivitet direkte, men fMRI giver et indirekte mål for blodets gennemstrømning i hjernen. Da iltet og afiltet blod har forskellig magnetisk resonans, kan MR-skanneren måle hvor der bliver brugt ilt i hjernen, og man kan formode at disse områder er aktive i forbindelse med den sproglige opgave. Fx har fMRI-undersøgelser på flere sprog vist at der er mere aktivitet i Brocas område når deltagere læser transitive sætninger med objektet først end når sætningerne har subjektet først (Kristensen \& Wallentin 2015). Denne ekstra aktivitet kan tyde på at Brocas område spiller en vigtig rolle $\mathrm{i}$ arbejdet med ledstilling, forudsigelse af sekvenser eller lignende. 
Foruden metoder til at måle hvornår og hvor sproglige processer finder sted $\mathrm{i}$ hjernen, kan man påvirke hjernens arbejde under sprogprocessering. Det kunne være påvirkning med alkohol eller hormoner, men man kan også med metoden TMS (transkraniel magnetisk stimulation) stimulere et udvalgt område af hjernen. Man kan fx kortvarigt gøre deltageren langsommere eller ude af stand til at tale (Pascual-Leone m.fl. 1991).

2.4.4 Andre metoder. Psyko- og neurolingvister kan også lave computersimulationer af hjernens aktivitet ( $\mathrm{fx}$ teste hvilke modeller der er hurtigst og bedst til at forstå sprog), studere menneskets gener (herunder "sproggenet" FOXP2: Graham \& Fischer 2015), sammenligne mennesker og abers kommunikation (Tomasello 2008) m.m.

I princippet kan psykolingvistik også være baseret på introspektion og være rent teoretisk, men sådanne teorier har typisk en kort levetid $\mathrm{i}$ det psykolingvistiske miljø - det er et psykolingvistisk mantra at teorier skal efterprøves empirisk på data fra psykolingvistiske eksperimenter, udviklingsstudier el. lign. som måler forankring i kroppen. Introspektion kan bruges til at udvikle en teori, der efterfølges kan efterprøves, men introspektionen er ikke nok alene.

Nogle psykolingvistiske metoder er let tilgængelige og billige i drift (software til reaktionstidsundersøgelse hentes gratis på nettet), men især mange neurolingvistiske metoder kræver en særlig infrastruktur med dyrt udstyr. Dertil kommer at opsætningen og dataanalysen af neurolingvistiske undersøgelser med EEG, fMRI eller TMS kræver specialviden fra andre fagområder. Psykolingvistikken er altså ikke bare tværfaglig i sine spørgsmål og teorier, men i høj grad også i sine metoder.

\subsection{Hvad er psykolingvistik ikke?}

Ikke alt der handler om sprog og kognition, er psykolingvistik ${ }^{1}$. Rent filosofiske eller essayistiske betragtninger der ikke systematisk forholder sig til sprog og kognition, er ikke at regne for psykolingvistik. Det er heller ikke psykolingvistisk forskning at lave litterære analyser med

1 Fx er terapiværktøjet neurolinguistic programming (NLP) ikke en forskningsretning og har, trods navnet, stort set ingen relation til neurolingvistisk forskning. 
kognitive vinkler. Hvis forskningen ikke forholder sig systematisk til sammenhænge mellem sprog og kognition og ikke opstiller falsificerbare hypoteser og modeller om strukturer og mekanismer som kan afprøves ved studier af menneskers adfærd eller neuroner, vil det dårligt kunne regnes for psykolingvistik. Men ikke-psykolingvistisk forskning kan sagtens være en inspirationskilde for psykolingvister.

Nogle psykolingvister definerer feltet snævert: Kontrollerede eksperimenter kan således ses omtalt som "the preferred psycholinguistic method" (Garrod 2006). Hvis man ser brugen af kognitionspsykologiske metoder som et krav for at kalde sig psykolingvist, udelukker det fx forskere der foretager ikke-eksperimentelle studier af raske personers sprog eller som opstiller teser uden at efterprøve dem selv eksperimentelt, herunder kognitive lingvister som George Lakoff.

2.5.1 Kognitiv lingvistik er ikee synonymt med psykolingvistik. Mens psykolingvistikken fra starten i 1950'erne var domineret af et generativt sprogsyn, blev den kognitive lingvistik dannet i 1970'erne i et oprør mod generativ grammatik (Evans \& Green 2006). Kognitive lingvister er optaget af at modbevise den generative grammatiks hovedteser, såsom tesen om at sprog er medfødt, mens nutidens psykolingvister ikke på samme måde er bundet op til en bestemt teoretisk ramme. Der findes både generativt orienterede psykolingvister og funktionelt orienterede psykolingvister - og der findes psykolingvister som ikke forholder sig til modsætningerne mellem funktionel og generativ lingvistik i deres forskning. Nogle psykolingvister ser også sig selv som kognitive lingvister, andre gør ikke.

Metodisk er mange psykolingvister inspireret af den kognitive psykologi, mens kognitive lingvister typisk benytter mere udpræget lingvistiske værktøjer som korpusstudier, semantiske analyser, typologiske studier og introspektion, og i mindre grad forholder sig til ikke-sproglige data. Fremtrædende teorier inden for den kognitive lingvistik som Lakoff og Johnsons metaforteori (Lakoff \& Johnson 1980) og Turner og Fauconniers blending-teori (Fauconnier \& Turner 2002) er kendetegnet ved at tage udgangspunkt i detaljerede sproglige analyser, mens deres modeller for sprogprocessering og -mekanismer er meget abstrakte og knapt så detaljerede som psykolingvistiske beskrivelser. 
2.5.2 Sprogpsykologi er ikke synonymt med psykolingvistik. Psykolingvistik er en betegnelse for et internationalt forskningsfelt, mens sprogpsykologi er navnet på en dansk uddannelse der kun udbydes på Københavns Universitet, og på forskningsmiljøet omkring uddannelsen. Sprogpsykologi bevæger sig, ligesom psykolingvistikken, i krydsfeltet mellem sprogforskning og psykologi, men er bredere orienteret. Sprogpsykologi har et stærkere fokus på sprog som interaktion end på sproget $i$ individet. Dette fokus på sprog mellem mennesker ses også i sprogpsykologiens centrale spørgsmål der dels omhandler hvad forholdet mellem sprog og forstålse er, dels omhandler i hvilken udstrækning sproget kan bruges til at skabe fælles forståelse med (Nielsen 2012:12). Den sprogpsykologiske forskning er i disse år især orienteret mod konversationsanalyser af læge-patient-samtaler og på at forbedre denne kommunikation (Nielsen 2012). Psykolingvistikken har traditionelt haft fokus på det eksperimentelle og biologiske, hvor sprogpsykologien orienterer sig mod de naturalistiske og sociale/interagerende aspekter inspireret af social- og personlighedspsykologi. Men nogle psykolingvister har også fokus på det naturalistiske og sociale, og som sprogpsykolog kan man også interessere sig for biologien (jf. Fogtmann 2014).

\section{PSYKO- OG NEUROLINGVISTIKKEN I DANMARK}

Danmark har, i modsætning til lande som USA, Tyskland og Holland, ikke haft nogen stærk tradition for at psykolingvistisk forskning informerer sprogvidenskaben. Forskere tilknyttet det audiologopædiske miljø har siden 1980'erne forsket i kommunikationsvanskeligheder forbundet med ordblindhed, høreskader og afasi. Men denne forskning har primært fokuseret på at udforske og afhjælpe sproglige afvigelser og har altså ikke primært handlet om at udforske dansk sprog eller bidrage til udviklingen af almene sproglige teorier. Sproget som kropsligt forankret har altså været et underbelyst emne i dansk sprogvidenskab. Først inden for de seneste årtier er der i Danmark opstået et egentligt psykolingvistisk miljø orienteret mod udforskningen af sprog hos raske sprogbrugere med konferencer, forskningsgrupper og psykolingvistiske ph.d.-afhandlinger. 
Psykolingvistikkens nylige indtog kan hænge sammen med at der omkring årtusindskiftet opstod en generel interesse for eksperimentelle tilgange i humaniora. Tylén og Wallentin (2015) tilskriver denne "1) en voksende interesse for menneskelig kognition, 2) en større interaktion med andre discipliner og 3) en dragning mod nye former for evidens" (Tylén \& Wallentin 2015: 344).

Tilsyneladende har psykolingvistikken indtaget Danmark gennem forskellige kanaler og miljøer. Mads Poulsens ph.d.-afhandling fra 2005 (fra Københavns Universitet) undersøger acceptabilitet og læsetider for sætningsknuder som Den whisky bliver hun fuld bvis bun baller inden fodboldkampen med afsæt i dansk funktionel lingvistik (Poulsen 2005). Samme år afleverede Ken Ramshøj Christensen (Aarhus Universitet) en ph.d.-afhandling om negationer og syntaktisk processering (Christensen 2005). Denne afhandling var bl.a. baseret på MR-skanninger, og havde også acceptabilitet af sætninger og sætningsprocessering som et tema, men med udgangspunkt $i$ generativ grammatik. I de følgende år fulgte neurolingvistiske ph.d.-afhandlinger fra Aarhus Universitet og Syddansk Universitet med et mere semiotisk, semantisk og interaktionistisk tilsnit (bl.a. Wallentin 2006, Tylén 2009), såvel som reaktionstidsstudier af morfologiske effekter på ordgenkendelse (Balling 2008) og eye-tracking-studier med fokus på anaforiske pronominer (Diderichsen 2008). Selvom alle disse afhandlinger bruger psyko- og/ eller neurolingvistiske metoder, er der stor bredde i temaer, såvel som i teorirammer.

Den amerikanske psykolingvistik er forankret i psykologien og i artificial intelligence-miljøer. Den danske forskning i psykolingvistik, derimod, udspringer primært fra de lingvistiske og semiotiske miljøer. Miljøerne har knopskudt siden årtusindskiftet og tæller bl.a. Interacting Mindscenteret (AU), Dansk Funktionel Lingvistik-gruppen i Københavnsområdet, Børn \& Sprog og Centre for Human Interactivity (SDU), ProGram-gruppen og Center for Sprogteknologi (KU) og CogLab (CBS) . Den øgede interesse for sprog og kognition har også resulteret i nye uddannelsesretninger som IT \& Cognition (KU) og senest Cognitive Science (AU). Nogle miljøer lægger hovedvægten på forståelsen af kognitive processer, andre på udforskningen af sprog. De udforsker alle sprog og kognition, men er også hver især forankret i forskellige 
forskningstraditioner og bruger ikke kun metoder fra kognitiv psykologi. Miljøerne kombinerer på forskellig vis psykolingvistiske metoder med andre lingvistiske metoder som korpuslingvistik, konversationsanalyse, datalingvistiske værktøjer, introspektion og typologiske undersøgelser. De mange tilgange kan bidrage til at dansk psykolingvistisk forskning samtænker hvad der sker i den enkelte sprogbrugers krop med fx forskelle mellem sprogbrugssituationer og sprogbrugeres kognition når de sammen bruger sprog.

\subsection{Den psykolingvistiske udforskning af dansk sprog}

Det er af flere grunde vigtigt med en psykolingvistisk udforskning af det danske sprog, både for lingvister og for andre faggrupper.

3.1.1 Teorier om kognition. Udforskningen af dansk sprog er vigtig for forståelsen af kognition. Hovedparten af psyko- og neurolingvistiske undersøgelser bruger stimuli på hovedsprog som engelsk og tysk. Men disse sprog repræsenterer ikke alle mulige sproglige træk. Teorier baseret derpå er ikke nødvendigvis typologisk adækvate (van Valin \& LaPolla 1997:8), og dermed får vi ikke hele sandheden om hjernens arbejde med sprog.

3.1.2 Anvendte perspektiver. Det er vigtigt at forstå det danske sprogs kognitive fundament, for der er forskel på genoptræning af engelsktalende personer og dansktalende personer. Hvis sprogtest til vurdering af ordblindhed eller skizofreni udarbejdes internationalt med udgangspunkt $i$ engelsk, har vi et problem når disse test oversættes til dansk. Klinisk forskning med dansk som stimuli kan desuden give værdifuld indsigt i sprogmekanismer hos raske talere og i sproglig klassifikation. Bl.a. kan test af grammatisk forståelse hos afasiramte give forstålse af dansk syntaks (Nyvad, Christensen \& Vikner 2014). Også ikke-kliniske studier kan have anvendte perspektiver. Fx kan studier i processering af informationsstruktur hjælpe os med at forstå hvordan vi skal skrive og tale så andre forstår det (Kristensen m.fl. 2014). 
3.1.3 Teorier om dansk. Resultater fra psyko- og neurolingvistiske undersøgelser kan også påvirke teorier om det danske sprog, fx om det danske fænomen stød. Blandt skandinaviske fonologer har det længe været omdiskuteret hvordan stød kan relateres til de svenske og norske ordtoner. Distributionelt og historisk minder stød om Accent 1 (dansk legen har stød, svensk leken har Accent 1), men det er omdiskuteret om stød eller ikke-stød er den markerede variant. Clausen \& Kristensen (2015) opsatte et lytteeksperiment med reaktionstidsmålinger hvor de undersøgte hvordan sprogbrugere reagerer på ord med og uden stød. Selvom dansk stød historisk og distributionelt minder om svensk Accent 1 , fandt dette studie at danske deltageres reaktionsmønstre for stød minder om den måde svenskere reagerer på Accent 2. Kognitivt er der altså fællestræk mellem stød og Accent 2 som distributionelle og sproghistoriske analyser ikke giver indsigt i.

\subsubsection{Retninger inden for udforskningen af dansk sprog. Forståelsen af me-} kanismer i sprogforståelse er relevant for stort set alle lingvister. Reaktionsundersøgelser kan hjælpe sociolingvister med at afdække ubevidste sprogholdninger og sprogprocesser eller give grammatikere nye perspektiver på begrebet grammatikalitet. Fx fandt Engberg-Pedersen og Poulsen (2010) at sætninger af typen De boger var hun helt vilde med... hvor det prædikative adjektiv vilde mod normen kongruerer med de bøger (og ikke med subjektet bun som normen tilsiger) blev hurtigere læst end sætninger uden nogen kongruens som Den bog var hun helt vilde med.... Også selvom begge sætninger afviger fra sprognormen og kunne regnes for ikke-grammatiske.

De psykolingvistiske undersøgelser afspejler allerede eksisterende interesser hos danske lingvister. Udforskningen af dansk ledstilling var fx et fremherskende tema i dansk lingvistik længe før psykolingvistikkens indtog i Danmark. De psykolingvistiske metoder har givet nye muligheder for at efterprøve teorier om rammerne for dansk syntaks ved at undersøge tilegnelse af ledstilling, forståelse af ledstilling, læsemønstre, aktivitet i Brocas område under sætningsprocessering m.m. (fx Boeg Thomsen \& Kristensen 2014; Kizach \& Balling 2013; Kristensen m.fl. 2014; Kristensen \& Wallentin 2015; Nyvad m.fl. 2014; Poulsen 2005). Generelt synes danske psykolingvister, i forhold til 
udenlandske psykolingvister, at være orienteret mere mod processering af flerordsforbindelser end af enkeltord - hvilket måske kan ses som en konsekvens af den grammatiske traditions fokus på ledstilling. Der findes også undersøgelser af processering af dansk prosodi (Clausen \& Kristensen 2015), morfologi (Balling 2008) og af enkeltord (pronominer: Diderichsen 2008; grammatiske vs. leksikalske ord: Vinther m.fl. 2014), samt undersøgelser af danske sprogbrugeres gestik og alignment (Christensen m.fl. 2016). Dermed afspejler psykolingvistikken de blandede temaer der i øvrigt behandles i forskelligartede danske sprogvidenskabelige miljøer. Men da psykolingvistiske metoder kræver klart afgrænsede falsificerbare hypoteser og ensartede stimuli, er der tale om enkeltnedslag $\mathrm{i}$ interessante problemstillinger snarere end omfattende sprogbeskrivelser som kendes fra anden sprogvidenskabelig forskning.

\section{PSYKOLINGVISTIKKENS STYRKER OG SVAGHEDER}

Psykolingvistikkens styrke er at den kan oplyse om hvad der sker i sprogbrugeren. Men dette fokus på hvordan hjernen lagrer sprog og arbejder med sprog er samtidig også psykolingvistikkens svaghed.

\subsection{Fokus er på målinger af kognitive processer}

Metoder som eye-tracking, EEG, TMS og fMRI har åbnet for en ny forståelse af sproglige processers timing og lokalisering, men samtidig er disse værktøjer dyre, metoderne er svære at tilegne sig, og resultaterne er svære at fortolke. Det er let at måle, men det er svært at tolke hvad det betyder for sprog og kognition når man måler noget - og ikke mindst hvad det betyder når man ikke måler noget (jf. afsnit 2.3 om the granularity mismatch problem). Hvad betyder det at en forsøgsdeltager bruger kort tid på at læse en type ord: Tog det kort tid fordi ordet var så svært at hun sprang det over? Eller tog det kort tid fordi ordet var let at forstå? Ligeledes er det svært at tolke betydningen af aktivitet i et hjerneområde. Mange studier viser som nævnt øget blodgennemstrømning i Brocas område ved læsning af sætninger med objektet først (vs. subjekt først), men hvilken konklusion skal man drage? Er Brocas område specialiseret $\mathrm{i}$ at håndtere ledstilling, $\mathrm{i}$ syntaktiske transformationer, $\mathrm{i}$ 
arbejdshukommelse eller i forudsigelse af sekvenser (se Kristensen \& Wallentin 2015 for en diskussion).

Der er diskrepans mellem de spørgsmål der kan informere sprogforskningen, og de spørgsmål som egner sig til en psykolingvistisk undersøgelse. Spørgsmålene er måske for brede med for mange variable, de lader sig ikke måle med eksisterende værktøjer, eller det teoretiske og empiriske forarbejde er ikke på plads. Det er derfor nødvendigt at tilpasse sine spørgsmål. Så almene sprogforskere må væbne sig med tålmodighed og se til, mens psykolingvister etablerer et fundament og påviser sammenhænge som for lingvisten er indlysende. Alle sproglige analyser viser at fonetik og grammatik involverer forskellige operationer, så det er ikke overraskende for lingvister at Sahin m.fl. (2009) finder at der er forskel på hjernens arbejde med fonetik og grammatik. Kun timingen og lokaliseringen af hjernens arbejde er ny information. Af og til er der dog "indlysende sandheder" der ikke bekræftes af psykolingvistiske undersøgelser, og så ses sprogteorierne i et nyt skær. Fx når musikalsk rytme aktiverer områder af hjernen der ellers forbindes med semantisk processering (Vuust m.fl. 2005), og der indikeres sammenhænge mellem rytme og semantik.

\subsection{Intern vs. ekstern validitet}

Psykolingvistikkens bestræbelser på at påvise årsagssammenhænge mellem sprog og kognitive processer fordrer at konklusioner ikke er påvirket af udefrakommende faktorer. Som tidligere nævnt fandt Kristensen m.fl. (2014) at forsøgsdeltagerne var længere tid om at læse sætninger med objektet først ( $\mathrm{fx}$ Else ville Kasper dog invitere til fodselsdagen) end sætninger med subjektet forst ( $x$ Kasper ville dog invitere Else til fodselsdagen). I forsøget var de to typer sætninger så ens som muligt. Der blev brugt de samme 32 verber og de samme 64 navne for begge typer ledstillinger, så der ikke var tvivl om at forskelle i læsetider skyldtes ledstilling og ikke $\mathrm{fx}$ at verberne eller navnene for de subjekt-initiale sætninger var mere frekvente end dem der blev brugt for de objektinitiale sætninger. Ligeledes blev der fx brugt den samme skrifttype og skriftstørrelse for begge typer ledstilling. Hvis man ikke holder sådanne faktorer konstante, ved man ikke om man har undersøgt forskellen på subjekt- vs. objekt-initiale sætninger, på højfrekvente vs. lavfrekvente 
verber eller på lille skriftstørrelse vs. stor skriftstørrelse. Ens konklusion får en lav intern validitet, dvs. man kan ikke konkludere om der var en årsagssammenhæng $i$ den givne situation.

Psykolingvistikkens fokus på at sikre høj intern validitet har desværre ofte konsekvenser for den eksterne validitet. Hvis en konklusion har en lav ekstern validitet, er det ikke sikkert man kan generalisere fra laboratoriesituationen til andre situationer. Det kan fx være svært at generalisere fra en situation hvor en deltager sad alene, ubevægelig og uforstyrret og læste ensartede sætninger på en skærm, og til at samme deltager lytter til sætninger der indgår naturligt i en samtale på en café. Men den naturalistiske situation har så mange variable, at de konklusioner man drager, bliver betydeligt svækkede, så man måske slet ikke har noget grundlag at generalisere og opstille sprogprocesseringsmodeller ud fra. Andre forskningstraditioner har det omvendte problem: Konversationsanalytikere vægter den naturalistiske situation højt og har svært ved at påpege årsagssammenhænge og generalisere. Selvom psyko- og neurolingvister ofte vægter den interne validitet højt (så de ved hvad de måler), er de bestemt ikke ligeglade med den eksterne validitet, og der er en bevidsthed i det psyko- og neurolingvistiske miljø om at konklusioner skal kunne generaliseres til flere sprog, til flere diskurskontekster (Kristensen \& Wallentin 2015), til nye populationer og til mere naturalistiske situationer (jf. Willems 2015). Men udviklingen sker med små skridt. Mange forsøg tester sprog hos unge højrehåndede mandlige amerikanske universitetsstuderende der læser ensartede enkeltord på en skærm. Så langt fra en naturlig samtale og med så snæver og kontrolleret en deltagergruppe, kan man diskutere om man faktisk undersøger sprog (jf. Tylén \& Wallentin 2015). Især neurolingvistikken fokuserer på sprogets forankring i kroppen (embodied cognition: Ward \& Stapleton 2012) og på årsagssammenhænge mellem sprog og biologi. Men sprog er som andre typer kognition også forankret i verden (embedded cognition) og i interaktion (enacted cognition: Ward og Stapleton 2012; Di Paolo \& Thompson 2014). Man kan se sprog, handling, kroppen og konteksten som stærkt forbundne, en tanke der længe har stået stærkt i det danske sprogvidenskabelige miljø. Eksempelvis er det en kongstanke i Dansk Funktionel Lingvistik at handling og kognition umuligt kan holdes fra hinanden og at "faktiske kommunikationsbegivenheder 
med deres fysiske og sociale dimensioner [er] input til den proces der skaber og vedligeholder sproglige strukturer" (Harder 2005:22). Selvom neurolingvister oftest belyser den kropslige forankring, kan de også være opmærksomme på at omgivelser og handlinger præger hjernens udformning. Kognitionsforskere som Mogensen (2011) argumenterer for hjernens plasticitet og evne til at reorganisere elementære funktioner baseret på stimuli fra omverdenen - selv efter en hjerneskade.

\subsection{Sprog er også forankret $i$ verden og handlinger}

Som nævnt har både danske og udenlandske studier undersøgt hvordan forsøgsdeltagere forstår sætninger med forskellig ledstilling. Der ses en stærk kobling mellem krop og sprog i disse forsøg, fx er der dårlige forståelse og større blodgennemstrømning $\mathrm{i}$ Brocas område for objekt-initiale sætninger. Når psykolingvistikken fokuserer på hvordan fænomenet ledstilling er forankret i og præget af kroppen, kan man let overse at ledstillingen også er forankret i og præget af handling.

Med ledstilling signalerer vi til vores samtalepartnere hvad der er hhv. ny og gammel information (fælles viden) i en sætning. Gammel information placeres fx typisk før ny. På den måde er brugen af ledstilling en sproglig handling: vi viser hvad samtalepartnerne skal fokusere på, og hvad vi regner med at de allerede ved i forvejen. Men når sætninger præsenteres enkeltvis "ud af det blå" uden kontekst og uden etablering af fælles viden, fjernes ledstilling fra både handling og situation.

I studiet af forskelle mellem subjekt- og objekt-initiale sætninger, undersøgte Kristensen m.fl. (2014) derfor om der er forskelle på sætninger vist $\mathrm{i}$ isolation vs. sætninger vist som del af en lidt længere tekst, hvor der opbygges delt viden mellem afsender og modtager. Forsøget viste at konteksten påvirker sætningsforståelsen: Forskellen i læsetid og i korrekt forståelse for objekt- vs. subjekt-initiale sætninger var mindre med delt viden (sætningen vist som del af en tekst) end uden delt viden (sætningen vist $\mathrm{i}$ isolation). Det kan altså have konsekvenser for forståelsen af ledstilling om man inddrager aspekter af en situeret handling $i$ sin undersøgelse eller ej. Psykolingvistikken har fortsat en stor opgave foran sig med at inddrage endnu flere naturalistiske aspekter i sine undersøgelser. 
I en amerikansk kontekst har bl.a. Anderson (2003) kritiseret den amerikanske kognitionsforskning for at hænge fast $\mathrm{i}$ dyndet fra en forældet formalistisk artifical intelligence-bevægelse og dermed overse at kognition er en situeret aktivitet. I Danmark er historien dog en anden. Det danske psykolingvistiske miljø udspringer ikke fra udforskningen af kunstig intelligens. Det udspringer overvejende af funktionelle, sociolingvistiske og interaktionelle miljøer der netop har fokus på sprog som handling. Sprog kan godt på en gang ses som et resultat af vores biologiske udvikling og som konstrueret gennem socialisering og handling (jf. Harder 2005).

Det danske sprogvidenskabelige miljø ved allerede at der er sprog mellem os, og at sproget påvirkes af sociale og kulturelle omstændigheder. Udfordringen er snarere at inddrage biologien og forstå hvad det betyder for dansk sprogforskning at sproget også er forankret i en krop.

\section{KONKLUSION}

Danske psykolingvister udspringer primært fra lingvistiske miljøer, snarere end fra psykologiske eller neurovidenskabelige. Til dagligt omgås de sociolingvister, konversationsanalytikere, fonetikere osv., og denne forankring $\mathrm{i}$ en dansk sprogvidenskabelig tradition præger temaerne i dansk psykolingvistik. Dansk psykolingvistik kan informere tilstødende lingvistiske discipliner og udforske dansk sprog, men har også sin egen dagsorden som handler om mekanismer og strukturer i hjernens arbejde med sprog. Selvom betegnelsen psykolingvistik har et generativt ophav, er der en stor teoretisk variation blandt danske psykolingvister - en del tænker allerede sprog, kognition og handling som tæt forbundne.

Psykolingvistik står stærkt $\mathrm{i}$ udforskningen af sprog som forankret $\mathrm{i}$ kroppen. Men hensynet til intern validitet går ofte ud over udforskningen af sprog som interaktion og som situationelt betinget, for mange psykolingvistiske eksperimenter løsriver sprogbrugeren fra en naturlig sprogbrugssituation. Internationalt er der dog en tendens mod mere naturalistiske forsøg. I Danmark udspringer psykolingvistikken fra miljøer med fokus på sociale og interaktionelle faktorer. Der kan derfor 
være håb om at dansk sprogforskning bliver embodied, embedded og enacted, ikke kun i teoretiske overvejelser, men også i empiriske undersøgelser med fokus på både intern og ekstern validitet.

Line Burholt Kristensen

Institut for Nordiske Studier og Sprogvidenskab

Københavns Universitet

burholt@hum.ku.dk 


\section{LITTERATURLISTE}

Ahlsen, Elisabeth. 2006. Introduction to neurolinguistics. Amsterdam: John Benjamins Publishing Company.

Andersen, Michael L. 2003. Embodied Cognition: A field guide. Artificial Intelligence 149. 91-130.

Balling, Laura Winther. 2008. Morphological effects in Danish auditory word recognition. Ph.d.afhandling. Aarhus Universitet.

Bock, Kathryn \& Willem J.M. Levelt. 1994. Language production. Grammatical encoding. M.A. Gernsbacher (red). Handbook of psycholinguistics New York: Academic Press. 741-779.

Boeg Thomsen, Ditte \& Line Burholt Kristensen. 2014. Semantic role assignment in Danish children and adults. Acta Linguistica Hafniensia 46(2). 159-198.

Bowerman, Melissa, and Soonja Choi. 2001. Shaping meanings for language: Universal and language-specific in the acquisition of spatial semantic categories. Melissa Bowerman \& Stephen Levinson (red.) Language acquisition and conceptual development. Cambridge: Cambridge University Press. 475-511.

Christensen, Ken Ramshøj. 2005. Interfaces: Negation - Syntax - Brain. Ph.d.-afhandling. Aarhus Universitet.

Christensen, Peer, Ricardo Fusaroli \& Kristian Tylén. 2016. Environmental constraints shaping constituent order in emerging communications systems: Structural iconicity, interactive alignment and conventionalization. Cognition 146. 67-80.

Clark, Herbert H. 1999. Psycholinguistics. Robert A. Wilson \& Frank C. Keil (red.) The MIT encyclopedia of the cognitive Sciences. MIT Press. 688-689

Clausen, Sara Juul \& Line Burholt Kristensen. 2015. The cognitive status of stød. Nordic Journal of Linguistics 38. 163-187.

Diderichsen, Philip. 2008. One of a kind. The processing of indefinite one-anaphora in spoken Danish. Ph.d.-afhandling. Lund Universitet.

Di Paolo, Ezequiel \& Evan Thompson. 2014. The enactive approach. Lawrence Shapiro (red.) The Routledge handbook of embodied cognition. London: Routledge. 68-78.

Engberg-Pedersen, Elisabeth. 2000. The interrelation of grammar, text type, and age: Expression of time relations and the pragmatic status of event participants in Danish narratives. Acta Linguistica Hafniensia 32(1). 121-141.

Engberg-Pedersen, Elisabeth \& Mads Poulsen. 2010. Alternative agreement controllers in Danish: Usage or structure? Kasper Boye \& Elisabeth Engberg-Pedersen (red.) Language usage and language structure. Berlin: de Gruyter Mouton. 205235. 
Evans, Vyvyan \& Melanie Green. 2006. Cognitive Linguistics. An Introduction. Edinburgh University Press.

Fauconnier, Gilles \& Mark Turner. 2002. The way we think: Conceptual blending and the mind's bidden complexities. New York: Basic Books.

Fogtmann, Christina. 2014. Forstålsens psykologi: Mentalisering i teori og praksis. Frederiksberg: Samfundslitteratur.

Fusaroli, Riccardo m.fl. 2012. Coming to terms quantifying the benefits of linguistic coordination. Psychological science 23. 931-939.

Garrod, Simon. 2006. Psycholinguistic research methods. Keith Brown (red.) The encyclopedia of language and linguistics 2. 251-257.

Graham, Sarah A. \& Simon E. Fisher. 2015. Understanding language from a genomic perspective. Annual review of genetics 49.19.1-19.30.

Harder, Peter. 2005. Dansk Funktionel Lingvistik - en introduktion. Elisabeth EngbergPedersen m.fl. (red.) Dansk Funktionel Lingvistik - en helhedsforståelse mellem sprogstruktur, sprogbrug og kognition. København: Københavns Universitet. 1-38.

Harder, Peter. 2006. Dansk Funktionel Lingvistik. NyS 34-35. 92-130.

Kizach, Johannes \& Laura Winther Balling. 2013. Givenness, complexity, and the Danish dative alternation. Memory and Cognition 41. 1159-1171.

Kristensen, Line Burholt, Elisabeth Engberg-Pedersen \& Mads Poulsen. 2014. Context improves comprehension of fronted objects. Journal of Psycholinguistic Research 43(2). 125-140.

Kristensen, Line Burholt \& Mikkel Wallentin. 2015. Putting Broca's region into context: fMRI evidence for a role in predictive language processing. Roel M. Willems (red.), Cognitive neuroscience of natural language use. Cambridge: Cambridge University Press. 160-181.

Kutas, Marta \& Steven A. Hillyard. 1980. Reading senseless sentences: Brain potentials reflect semantic incongruity. Science 207. 203-205.

Levelt, Willem J.M. 2012. A history of psycholinguistics: the pre-chomskyan era. Oxford: Oxford University Press.

Libben, Gary. 1997. Psycholinguistics: the study of language processing. William D. O'Grady, Michael Dobrovolsky \& Francis Katamba. Contemporary Linguistics. London: Longman. 438-462

MacDonald, Maryellen, Marcel Adam Just \& Patricia A. Carpenter. 1992. Working memory constraints on the processing of syntactic ambiguity. Cognitive Psycho$\log y$ 24(1). 56-98. 
Mechelli, Andrea m. fl. 2004. Structural plasticity in the bilingual brain. Nature 431 (7010). 757.

Nielsen, Søren Beck. 2012. Sprogpsykologi. Det teoretiske grundlag. Frederiksberg: Samfundslitteratur.

Nyvad, Anne Mette, Ken Ramshøj Christensen \& Sten Vikner. 2014. The left periphery and agrammatism: Wh-extractions in Danish. Enoch Oladé Aboh, Maria Teresa Guasti og Ian Roberts (red.) Locality. New York: Oxford University Press. 254-273

Pascual-Leone, Alvaro, John R. Gates \& Anil Dhuna. 1991. Induction of speech arrest and counting errors with rapid-rate transcranial magnetic stimulation. Neurology 41(5). 697-702.

Poeppel, David \& David Embick. 2005. Defining the relation between linguistics and neuroscience. Anne Cutler (red.). Twenty-first century psycholinguistics: Four cornerstones. London: Lawrence Erlbaum Associates, Inc. 103-118

Poulsen, Mads. 2005. Sentence processing and grammaticality in functional linguistics: extraction in Danish as an example. Ph.d.-afhandling. Københavns Universitet

Sahin, Ned T. m.fl. 2009. Sequential processing of lexical, grammatical, and phonological information within Broca's area. Science 326. 445-449

Tomasello, Michael. 2008. Origins of human communication. MIT Press.

Tylén, Kristian. 2009. Roses, Icebergs, Hoovers and all that language: An investigation of the cognitive foundation of our comprehension of object mediated communication. Ph.d.-afhandling. Syddansk Universitet.

Tylén, Kristian \& Mikkel Wallentin. 2015. Eksperimenter i humanistisk forskning. David Budtz Pedersen, Frederik Stjernfelt og Simo Køppe (red.). Kampen om disciplinerne. København: Hans Reitzels Forlag. 343-368.

van Valin, Robert D. \& Randy LaPolla. 1997. Syntax. Structure, meaning and function. Cambridge: Cambridge University Press.

Vinther, Nicoline Munck, Kasper Boye \& Line Burholt Kristensen. 2014. Grammatikken i baggrunden: Opmærksomhed under læsning. NyS 47. 99-139.

Vuust, Peter, Andreas m.fl. 2006. It don't mean a thing...: keeping the rhythm during polyrhythmic tension, activates language areas (BA47). Neuroimage 31(2). 832 841.

Wallentin, Mikkel. 2006. Neural processing of sentences with spatial meaning. Ph.d.-afhandling. Aarhus Universitet. 
Ward, Dave, and Mog Stapleton. 2012. Es are good. Cognition as enacted, embodied, embedded, affective and extended. Fabio Paglieri (red.) Consciousness in Interaction: The role of the natural and social context in shaping consciousness. 131-160.

Wiben Jensen, Thomas \& Martin Skov. 2007. Forord. Thomas Wiben Jensen \& Martin Skov (red.). Folelser og kognition. København: Museum Tusculanums Forlag. 7-8.

Willems, Roel M. (red.). 2015. Cognitive neuroscience of natural language use. Cambridge: Cambridge University Press. 